\title{
The effectiveness of group counseling based on islamic value to reduce the late behaviour of students
}

\author{
Sofyan Abdi ${ }^{1}$, Dwi Endrasto Wibowo ${ }^{2}$, Sa'adah $^{3}$ \\ ${ }^{1,2}$ Universitas Islam As-Syafi'iyah, Jakarta, Indonesia \\ ${ }^{3}$ Universitas Negeri Semarang, Indonesia \\ sofyanabdi.fkip@uia.ac.id
}

Submitted : 12-09-2020, Revised : 16-09-2020, Accepted : 28-11-2020

\begin{abstract}
Discipline is a positive and constructive force in shaping children's character related to the environment; the application of disciplinary values must be carried out continuously, to achieve all expected goals. The purpose of this study was to determine the effectiveness of Islamic value-based group counselling to reduce students' late behaviour. The instrument used in this study was a late behaviour questionnaire. The research was conducted at one of Budi Mulia Utama Senior High School in East Jakarta, with 8 students as the research subject. The design that will be used is one group pretest-posttest design. The results of the t-test data analysis showed that Islamic value-based group counselling was effective in reducing students' late behaviour. The findings in the field show that students' late behaviour has decreased after being given group counselling services. Group counselling is carried out by internalizing Islamic values related to discipline in service content at each stage of its implementation. Cultivating Islamic values builds children's awareness of discipline and values time and forms a responsible character.
\end{abstract}

Keywords: Group Counselling; Islamic Values; Late Behaviour.

\section{Introduction}

Formal, non-formal and informal education must always instil disciplinary values in the learning process. Discipline is a feeling of being obedient and obedient in doing certain work for which they are responsible or in other words, an action taken by someone in carrying out the responsibilities that must be done. Student discipline can be seen from the obedience (compliance) of students to the rules (rules) related to school hours including school entry and exit hours, student compliance in dress, student compliance in attending school activities, and so on. All student activities whose compliance is seen are related to educational activities at school, which are also associated with life outside the school environment (Pekaar et al., 2017). Discipline is also a positive and constructive force in shaping children's character related to the environment. This awareness is the most important part that must be owned by children because it is very influential in instilling the value of discipline (Rabbani, 2020).

The application of disciplinary values must be made continuously and usually every day; The implementation is carried out by providing real examples that the children can take their values and role models from. In addition to awakening or resuscitating students, this also needs to be balanced with the teacher's efforts to add value to bad behaviour for future lives and will be followed by punishment or reward. Teaching helps develop self-control and student direction to provide education in developing a conscience to guide oneself to discipline in every action taken (Hurlock, 2000). So that children can be disciplined in essence lies in self-control which is based on the desire to cultivate self-order, obedience to rules/order arising from the individual's internal awareness. Self-control is meant to be a conscious state of one's thoughts and feelings.

The most difficult challenges for adolescents are interaction and adjustment with increasing peer influence, changes in social behaviour, social grouping, new values in choosing friendships, support, social rejection, and the election of leaders (Bulantika et al., 2018). 
Self-control is an action in the form of love and is a choice from within the individual or self (internal awareness), not a choice imposed from outside that contains aspects, these aspects are (a) behavioural control (behavioural control is a readiness to respond directly to influence unpleasant situations, (b) negative control (cognitive control) is the ability to process unwanted information by making interpretations, judgments or linking events in a cognitive framework as a psychological adaptation to reduce stress, and (c) Decisional control is the ability to choose actions based on something believed (Bailey, 2004; Gilliom et al., 2002).

Based on (Sudrajat, 2008) Every student is required and expected to behave by the rules and regulations applicable in the school where the student is studying. The behaviour, rules and regulations that apply in these schools can be grouped into two groups, as follows:

1) Compliance and obedience of students to various laws and regulations in force in their schools; this is commonly referred to as student discipline.

2) Legislation and various other provisions are an attempt to regulate student behaviour so that schools are disciplined.

Based on observational data about the late behaviour of students in a private high school in East Jakarta, together with the school counsellor, late behaviour is a classic thing that is very often done by students. The number of delays reached 18 times with 8 students in just 2 months. The data shows that private high school students for the 2018/2019 academic year have a level of late behaviour that needs to be considered or taken seriously.

Disciplinary problems such as late behaviour are essential for finding solutions. Being late is deviant behaviour that violates the rules of discipline at school, being late in school has a bad impact on the learning process and will further affect the learning achievement of students who arrive late and can affect the concentration of students participating in the learning process in class (Amemiya et al., 2020). One of the alternatives to reduce late behaviour is to provide group counselling services. The implementation of group counselling services is given to several students to obtain certain benefits and alleviate student problems that cause late behaviour.

By using group activities, students are expected to understand and understand that late behaviour is negative behaviour that must be changed through understanding and volunteering. Group dynamics is a study that describes the various forces that determine the behaviour of members and group behaviour that cause changes in the group to achieve common goals that have been set. Group dynamics are psychological relationships that take place together from group members, paying attention to human behaviour in small groups and the forces that exist in the group, the causes for the growth of these powers and their influence on individuals, groups and their environment (Hoey et al., 2018).

One of the duties of the guidance and counselling teacher is to show the direction and path the student will take. School counsellors try to prevent students from doing things that are detrimental to themselves and the environment, both family, surrounding community and the wider community. The speciality of guidance and counselling in schools is a service that upholds religious values. Not the rules imposed by the government and schools because religious values are fundamental, universal, and absolute (Bakran, 2004).

In its implementation, group counselling will be accompanied by Islamic values to provide an understanding that respecting time is the main thing. As Allah SWT says in Surah Al-Asr verses 1-3 which means: "With time. Humans are at a loss. Except for those who believe, and do good, and encourage the truth, and encourage patience." (Translate by quranful.com).

If we are aware that every day we remember what is called the five daily prayers, What a very orderly time, it is all presented by Allah SWT, one of which is a reminder that timeliness in activities is something good and must be owned by every individual. An orderly 
and orderly life greatly determines the success or failure of a person in managing time in a disciplined manner and its relationship with late behaviour which will also determine one's success or failure.

Therefore, as a good Muslim, one must be able to make the most of his time for worshipping Allah SWT. Imam Magid said that "Islamic counselling emphasizes spiritual remedies, based on love and fear of Allah and the obligation to fulfil our responsibilities as servants of Allah on this earth. This confirms that Islamic counselling is an effort to solve spiritual problems based on faith, obedience, and perseverance in following His orders to act as a leader on earth (Lubis, 2011). The essence of Islamic counselling is the effort to help Muslim men and women to develop a self-image that believes as Muslim. Islamic counselling has two dimensions - spiritual and material. The spiritual dimension is a central part of Islamic counselling. The goal is focused on gaining comfort, which is only found in the purity of resources, namely Allah SWT (Lubis, 2011).

Besides, it focuses on morals, is aimed at things that purify spiritually, draw closer to Allah and praiseworthy qualities, such as patience, tawakkal, qana'ah (feel enough with what is there), and so on. Therefore, the importance of planting Islamic values. And the object of morals is the human spirit (Zakaria \& Akhir, 2017). Guidance and counselling activities are also aimed at shaping morals, and morals are contained in all pillars of Islam. And from the value of moral guidance and counselling, the output of Islamic guidance and counselling will be obtained, namely morals, with the formation of muttaqîn beings. In this study, to be more specific in the application and implementation of group counselling services with Islamic values related to the tardiness of children in school is a strong impetus for children to form their identity and self-image as a highly disciplined Muslim. And value your time as best as you can.

\section{Methods}

Based on the problems and research objectives, the type of research used is preexperimental research. In this study, the control group was not used because it only provided treatment to the group experiencing problems - the data collection technique in this study as a student's final behaviour questionnaire.

The questionnaire validity test was conducted on 30 respondents; for the results of the validity test, the late questionnaire consists of 65 statements. Statement items that are declared valid and invalid. 40 valid statement items and 25 invalid statement items will be deleted or deleted on this questionnaire scale. Meanwhile, 40 items were declared valid and can be used as a data collection tool. The instrument used in this study was the late behaviour instrument developed from Supriyanto (2012). In this study, the results of the instrument reliability test were $r=0.940$. If seen in the Correlation Coefficient Interpretation table above, that the value of $\mathrm{r}$ is at the level of $\pm 0.80- \pm 1,000$, which states that this psychological scale statement is on the test results. Reliability is sturdy.

The subjects in this study were students of class X SMA Budi Mulia Utama Jakarta who were identified as having high late behaviour. To determine the research subject, 63 students who sat in class $\mathrm{X}$ were measured by giving a late behaviour questionnaire. Giving a questionnaire aims to determine the score of late behaviour in students before being given Islamic value-based group counselling to be the research subject. The measurement results are then grouped into three categories, namely high, medium and low. From the results of the categorization guidelines, it was found that 8 students were in the high category. Therefore, 8 students were used as research subjects. The data analysis used was descriptive statistical data 
analysis to describe or present the data that had been collected in the sample, to determine the effectiveness of the comparison results using t-test analysis using the SPSS software program

\section{Results and Discussion}

The results showed that Islamic values-based group counselling services were effective in reducing students' late behaviour. For the objective conditions of students' late behaviour can be seen in table 1 .

Table 1. The Level of Late Behaviour

\begin{tabular}{lcc}
\hline Category & $\begin{array}{c}\text { Number of } \\
\text { Students }\end{array}$ & Percentage \\
\hline High & 8 & $36 \%$ \\
\hline Medium & 33 & $61 \%$ \\
\hline Low & 22 & $3 \%$ \\
\hline
\end{tabular}

Based on table 1, it can be concluded that there is a need for assistance to students so that students can reduce tardiness. School counsellors also desperately need appropriate and effective and efficient group counselling services to reduce students' high late behaviour. The questionnaire data above is also supported by the results of observations carried out for 1 week, based on the results of these observations, it was found that there was a high rate of late behaviour, namely about 20 late cases, likewise with the results of documentation taken from the student's behaviour book, which is filled in late every day by the picket teacher assisted by the school counsellor.

In this case, it is necessary to implement Islamic value-based group counselling services because all these interventions can reduce tardy student behaviour. Test the effectiveness of Islamic value-based group counselling services to reduce tardiness of students by 4 meetings by determining the topics to be discussed in the activity. The topics discussed were (1) the importance of disciplinary behaviour as a religious person; (2) discipline in Islam; (3) self-control; (4) Time management in Islam.

Based on the normality test on the pretest (sig. 110> 0.05) and posttest (sig .200> 0.05 ) data, it can be concluded that the data in this study were normally distributed so that the $\mathrm{t}$-test could be continued. Then from the t-test results in the sig value. 0.002 and a counting score of 4,922. The effectiveness test was developed at the same time to answer the research hypothesis by comparing the difference between the pre-test and post-test scores using the ttest. There is a significant difference in the score of treatment services before and after being given ( $\mathrm{t}$ count $=4.922>\mathrm{t}$ table $=2.44691)$, these results indicate that there is a significant difference between pretest and posttest data, which means the results of the research are based on Islamic values. Group counselling services are effective in reducing tardy student behaviour. Many factors cause the delay of students coming to school.

These factors greatly affect the discipline of going to school. The discipline of leaving for school has a major effect on student learning outcomes or even affects teaching and learning activities in the classroom. The factors causing the habit of students being late for school include waking up late, no one delivering, deliberately arriving late to school, delaying going to school and waiting for friends, the distance from the schoolhouse that is far away from a leaky motorbike tire. A study said the factors themselves have an important influence in causing the habit of being late for school, including waking up late due to unhealthy body conditions and the desire to leave late for school (Arisukwu et al., 2019). Supported by research which states that students' delay in school is caused by several factors, namely factors that come from themselves (for example, lazy to wake up early, deliberately delaying going to school), family and environmental factors (Das-Friebel et al., 2020). 
Family factors, namely the upbringing of parents are very influential on the discipline of children, especially the discipline of going to school, if the child has been accustomed to discipline since childhood, the child will continue to apply discipline at home, school and the surrounding environment. Apart from self and family factors, environmental factors also greatly influence the tardiness of students in school, namely the social environment. In line with research that finds friends greatly affect discipline, if children hang out with friends who are diligent in coming to school on time, then the child will be motivated to come to school on time and vice versa if the child mingles with friends who are often late for school then the child is usually also participating in trying to come late to school (Putrati et al., 2018). By implementing group counselling based on Islamic values, students have an awareness that they have responsibilities and priorities in life today.

Observational data also support these results after treatment, which is given to control whether late behaviour still occurs or decreases. Based on the results of observations after treatment, there was a significant change. This can be seen from the number of late behaviour that decreased by 5 cases in 1 week.

This is in line with the findings of previous research on tardiness (Thalib \& Syahran, n.d.) Regarding the effect of group behaviour counselling techniques and reinforcing to reduce tardiness in schools, it is stated that group counselling behaviour and reinforcement have a positive effect on reducing tardiness of secondary school students in school. This is due to changes in student tardiness in school before and after participating in group contract counselling behaviour and reduced reinforcement.

This is also in line with research conducted by Hamidiyah which states that he has succeeded in disrupting student behaviour, this is indicated by changes in the behaviour of the counselee in his daily life which initially are less able to manage time well, become more able to manage his time and be responsible so that you can live more discipline.

Self-management techniques in group guidance can help students train themselves to be more organized in carrying out their learning obligations, manage free time to play, increase learning motivation and manage time, so they don't wake up late and end up late for school. In the end, the number of tardiness for class X SMA Gebog 1 students can be reduced (Alamri, 2015). Furthermore, an individual approach to behavioural counselling services can address late attendance behaviour at school. In this case, it can be concluded that the application of counselling services is the wrong way or good intervention carried out by School Counselors in Schools to reduce or reduce students' late behaviour (Supriyanto, 2012).

Counselling with Islamic values will be more easily accepted among the majority of Muslims who are familiar with Islamic teachings in their families and communities. Muslim children in Indonesia must understand and know that Islam is an important part of life. Have full awareness of people's beliefs, traditions, and values and take care to avoid confrontation. Some components of genetic counselling are sensitive points, and movement from one social context to another requires careful consideration. In the Islamic / Arab community, because of strong religious beliefs, social reservations, and the importance of customs, the genetic counselling process should be directed to provide maximum benefit within an appropriate framework (El-Hazmi, 2004).

Delays often arise because children lack discipline and respect time, in Islam, it is important to instil in children, awareness of discipline and respect for time will form characters that will help children develop optimally, such as children who will be able to manage time well and know their obligations as school-age children with Islamic concepts they understand. This is in line with research (Hanin Hamjah \& Mat Akhir, 2014) the results of his research explain that the Islamic approach applied in counselling has positive implications for both. Counsellors and clients. Thus, it can be concluded that the Islamic 
counselling approach has the potential to help clients overcome problems, and this needs to be continued to increase the effectiveness of counselling.

Based on these findings, it can be concluded that the implication for each counsellor to reduce students' late behaviour is to provide appropriate Islamic value-based group guidance services. Based on (Lickona, 2012), Good character is supported by the knowledge of goodness, willingness to do good and do good. Another important thing is the availability of time in the implementation of group counselling services based on Islamic values as a process of improving Islamic behaviour. This study still has several limitations; One of them is an empirical evaluation which is only conducted in one group to determine its effectiveness. Therefore, this study has not been repeatedly investigated (follow up) to determine the other effects of Islamic value-based group counselling to reduce students' late behaviour.

\section{Conclusions and Suggestions}

Based on the results of the study, it can be concluded that the application of Islamic value-based group counselling to reduce students' late behaviour proved effective. This is based on the results of field tests which show that after participating in Islamic value-based group counselling, students' late behaviour is reduced. By cultivating Islamic values, it builds children's awareness of discipline and respect for time and forms character that will help children develop optimally, such as children who later manage time well, knowing their obligations as children who are school-age children with Islamic concepts that they understand.

Suggestions from the findings of this study are that school counsellors can provide Islamic value-based group counselling services to reduce student late behaviour to support the implementation of group guidance services with an Islamic background, for further researchers to be able to develop this field of study by paying attention to internal aspects such as family, status. economy and social status specifically as supporting factors or inhibiting the formation of discipline, especially late behaviour

\section{References}

Alamri, N. (2015). Layanan bimbingan kelompok dengan teknik self management untuk mengurangi perilaku terlambat masuk sekolah (studi pada siswa kelas X SMA 1 Gebog tahun 2014/2015). Jurnal Konseling GUSJIGANG, 1(1).

Amemiya, J., Mortenson, E., \& Wang, M.-T. (2020). Minor infractions are not minor: School infractions for minor misconduct may increase adolescents' defiant behavior and contribute to racial disparities in school discipline. American Psychologist, 75(1), 23.

Arisukwu, O. C., Olaosebikan, D., Asaleye, A. J., \& Asamu, F. (2019). Feeding habit and the health of undergraduate students: Evidence from Nigeria. The Journal of Social Sciences Research, 5(2), 498-506.

Bailey, B. A. (2004). Easy to love, difficult to discipline: Tujuh keterampilan dasar untuk mengubah konflik menjadi kerja sama. Gramedia Pustaka Utama.

Bakran, H. (2004). Konseling \& psikoterapi islam. Fajar Pustaka Baru.

Bulantika, S. Z., Wibowo, M. E., \& Jafar, M. (2018). Group counseling with systematic desensitization techniques and thought-stopping techniques to reduce social anxiety. Jurnal Bimbingan Konseling, 7(2), 106-112. 
Das-Friebel, A., Gkiouleka, A., Grob, A., \& Lemola, S. (2020). Effects of a 20 minutes delay in school start time on bed and wake up times, daytime tiredness, behavioral persistence, and positive attitude towards life in adolescents. Sleep Medicine, 66, 103-109.

El-Hazmi, M. A. F. (2004). Ethics of genetic counseling - basic concepts and relevance to Islam ic com m unities. 24(April), 84-92.

Gilliom, M., Shaw, D. S., Beck, J. E., Schonberg, M. A., \& Lukon, J. L. (2002). Anger regulation in disadvantaged preschool boys: Strategies, antecedents, and the development of self-control. Developmental Psychology, 38(2), 222.

Hanin Hamjah, S., \& Mat Akhir, N. S. (2014). Islamic approach in counseling. Journal of Religion and Health, 53(1), 279-289. https://doi.org/10.1007/s10943-013-9703-4

Hoey, J., Schröder, T., Morgan, J., Rogers, K. B., Rishi, D., \& Nagappan, M. (2018). Artificial intelligence and social simulation: Studying group dynamics on a massive scale. Small Group Research, 49(6), 647-683.

Hurlock, E. B. (2000). Perkembangan anak: jilid 2 / Elizabeth B. Hurlock; alih bahasa. Erlangga.

Lickona, T. (2012). Character matters. Diterjemahkan oleh J. A. Wamaungo dan J. A. R. Zien. Bumi Aksara.

Lubis, S. A. (2011). Islamic counseling: The services of mental health and education for people. Religious Education, 106(5), 494-503. https://doi.org/10.1080/00344087.2011.613347

Pekaar, K. A., van der Linden, D., Bakker, A. B., \& Born, M. P. (2017). Emotional intelligence and job performance: The role of enactment and focus on others' emotions. Human Performance, 30(2-3), 135-153.

Putrati, F., Wahyuningsih, H., \& Rachmawati, M. A. (2018). The effect of group counseling to the discipline improvement of student's learning in islamic junior high school in Yogyakarta. Advanced Science Letters, 24(7), 5374-5379.

Rabbani, A. G. (2020). Cash value life insurance ownership among young adults: The role of self-discipline and risk tolerance. Journal of Behavioral and Experimental Finance, 27, 100385.

Sudrajat, A. (2008). Pengertian pendekatan, strategi, metode, teknik dan model pembelajaran. Sinar Baru Algensindo.

Supriyanto, A. (2012). Mengatasi perilaku terlambat datang ke sekolah melalui layanan konseling individual pendekatan behavioristik dengan teknik behavior shaping di SMP negeri 19 Semarang tahun ajaran 2011/2012. Indonesian Journal of Guidance and Counseling: Theory and Application, 1(1).

Thalib, M., \& Syahran, R. (n.d.). Pengaruh konseling kelompok teknik kontrak perilaku dan pemberian penguatan terhadap pengurangan keterlambatan di sekolah (studi SMP negeri 4 Palu). Jurnal Konseling Dan Psikoedukasi, 3(2), 72-85.

Zakaria, N., \& Akhir, N. S. M. (2017). Theories and modules applied in Islamic counseling practices in Malaysia. Journal of Religion and Health, 56(2), 507-520. 
